\title{
YOUTUBE VLOGGING: PROMOTING SELF-REGULATION IN PUBLIC SPEAKING
}

\author{
Samsul Khabib \\ Universitas Katolik Widya Mandala Surabaya \\ samsulkhabib@unipasby.ac.id
}

\begin{abstract}
This paper explored the use of YouTube video blogging (vlogging) to promote self-regulation in an English for Public Speaking class. The self-regulation includes four essential components namely planning, monitoring the plans, controlling and changing the plans, and reflecting on the works. Furthermore, the investigation was to determine what self-regulation improvement has developed through YouTube vlogging and how YouTube vlogging can improve students' self-regulation. The research method was a Classroom Action Research. To obtain the data, Self-Regulation Questionnaires in the Pre-Survey and Post-Survey, students' journal entries and semi-structured interviews were employed as the instruments. Then, the data were analyzed using Quantitative and Qualitative approaches. The data analysis results show that participants improve their self-regulation. The improvement can be seen from the results of the Post-Survey compared to Pre-Survey and the second students' journal entries compared to the first students' journal entries. Furthermore, the results of semi-structured interviews reveal that the improvement was caused by the process of YouTube vlogging creation.
\end{abstract}

Keywords: Self-regulation, public speaking, YouTube vlogging

\section{INTRODUCTION}

Education providers have recognized that public speaking studies and practices have become a critical part in helping students find their voices (Turner, Osborn, Osborn, \& Osborn, 2018). Skills in public speaking will give an unquestionable edge. Presently, like never before, public speaking has turned out to be both a crucial fundamental ability and a strong weapon in vocation advancement (O'Hair, Rubenstein, \& Stewart, 2016). However, Lucas (2009) argued that public speaking is more complex than a daily conversation because it is more highly structured, needs more formal language, and requires a different method of delivery. Those three major differences require both teachers and students to adapt and think more critically. Furthermore, the differences often make teachers and students meet difficulties in the public speaking teaching and learning process.

Since English is regarded as a foreign language in Indonesia, the opportunity to practice speaking is very limited. Thus, Indonesian students often find common problems faced when they have English language subject including public speaking. One of the serious problems faced is anxiety (Anandari, 2015). To solve this problem, teachers need to encourage their students to practice more 
especially out of the classrooms since they need more time to practice which cannot be provided in the classroom. Thus, in this research, the researcher would like to formulate problem solving by trying to encourage students to practice speaking with technology aids.

Multifarious technologies are used in the teaching and learning process. One of them is YouTube. It is a famous platform with 1.68 billion users in 2019 (www.statista.com). Thus, it can become one of the alternative means that help students in developing their skills in speaking English. However, research found that the use of technology itself does not always help students in learning when the students do not have self-regulation. Yot-Domínguez \& Marcelo (2017) mentioned that students who were limited in cooperating the technologies with their self-regulation of learning tend to fail to achieve the learning goals. Afterward, it becomes more interesting to find more about the role of YouTube regarding promoting self-regulation in public speaking as already discussed above. Finally, to investigate the role of YouTube in promoting students' self-regulation in public speaking became the focus of this study.

\section{THEORETICAL REVIEW}

Zarei \& Gilanian (2015) stated that self-efficacy is one of the components of the motivational self-regulated learning which has a major role in teaching and learning. Furthermore, Self-efficacy takes an important part in promoting one's self-regulation. Self-efficacy affects learners' self-regulation.

According to Bandura (1997), self-efficacy beliefs are constructed from four principal sources of information: enactive mastery experience, vicarious experience, verbal persuasion, and physiological and affective states. The first source is enactive mastery. Enactive mastery experience is also called performance accomplishment. The successful experience in doing a task or job makes somebody become more confident to do other things in the future. The more difficult to succeed the more confident to be. The second source of selfefficacy is a vicarious experience. People think that when somebody else could handle a task or job successfully, they can be as well. The third source of selfefficacy is verbal persuasion. It leads people to believe that they own the competence to gain what they quest. The last source is called physiological and emotional states. People count on their somatic information led by physiological and emotional states when they appraise their abilities.

Mahmoodi, Kalantari, \& Ghaslani (2014) found that self-regulation and motivation work closely to simplify EFL learners' learning and success in the classroom. According to Dornyei (2005), self-regulation is the level used by learners in their own learning in acquiring the language. Furthermore, in terms of language learning, self-regulation is considered as the strategies used by students in controlling their motivation to learn.

With self-regulation, students are demanded to be more proactive since they are already aware of their abilities owned and guided by individual tasks and goals. Then, this takes us to an important question of how self-regulation is processed by learners.

The first step of self-regulation is the forethought phase. Zimmerman (2002) classified this phase into; task analysis which includes goal setting and strategic planning. The next step is the central step. It is performance phase which is 
divided into two main classes: self-control and self-observation People may think that self-control is the core of learning, however it is just the way of learners to develop their strategies in learning processes. Self-observation, still according to Zimmerman (2002) refers to a self-recording personal events of selfexperimentation. Lastly, it is a self-reflection that consists of self-judgment and self-reaction. The self-judgment process includes self-evaluation that refers to comparisons of self-observed performance compared to the standard. The selfreaction involves the self-satisfaction and affect regarding one's performance.

Research found that learners need to learn to regulate their own ways of learning for some reason. For example, El-Sakka (2016) stated that selfregulation strategies can help learners speak and develop their speaking ability. Furthermore, Ekhlas \& Shangarffam (2013) assert that environmental selfregulation has a positive relationship in speaking. There are several measurements used to access self-regulation in speaking. One of the most popular instruments employed in self-regulation measurement is the Self-Regulation Questionnaire developed by Brown, Miller \& Lawendowski (1999).

Santagata \& Guarino (2011) studied the use of video to teach future teachers. The result showed that the use of video-based activities helped teachers make students thinking visible. In further support of this finding, DeWitt et al. (2013) studied the potential of YouTube for teaching and learning. It was found that YouTube was beneficial for providing information as well as for teaching and learning. Additionally, YouTube has become one of the most used social media to teach and learn English (Alhamami, 2013).

\section{METHOD}

The research method used to gain the answers to the research questions: What self-regulation improvements has YouTube vlogging made on students in a public speaking class? and how can YouTube vlogging promote students' selfregulation in public speaking? The research method consists of research design, subject/ participants, source of data, data, unit of analysis, instruments, data collection, data analysis, and triangulation.

\section{Research Design}

The method employed in this research was a Classroom Action Research. This type of research is designed systematically for teachers (Bell \& Aldge, 2014). It is believed that this method could represent the students' differing views along with the teachers (Gilmer, 2010). CAR is a series of actions done by teachers to solve problems at a particular scope in an educational setting such as in a classroom.

CAR helps teachers to gain more understanding about the teachers themselves, classrooms and students. It is proposed that CAR fits to be done based on a particular subject. Furthermore, a researcher needs to plan before conducting the research. It will help not only the researcher but also the students to understand more the purpose of the activity and what is required.

Afterward, the researcher implements the planning into action which is followed by an observation. Observation is needed since it becomes the basis of the reflection and also the re-planning, new acting, observation and further reflecting (Kemmis, McTaggart, \& Nixon, 2014). 


\section{Participants}

This research was conducted at a private university in Surabaya. The reasons to choose this university to be the research site are: first, this university has a department called English Language Education Department which prepares pre-service teachers of English as a foreign language; second, one of the subjects taken by the students in this department is English for Public Speaking. There were 6 male and 11 female students in the class. Furthermore, The English for Public Speaking has a two-credit course. It means that this course had $2 \times 50$ minutes of weekly face-to-face meetings or classroom sessions, 2 x 60 minutes of independent learning, and 2 × 60 minutes of structured assignments.

\section{Measures}

To gain the data, the researcher employed some instruments namely selfregulation questionnaire, students' journals, and semi structured-interview supported with the researcher's reflective notes. The Self-Regulation Questionnaire with 22 questions adopted from http://www.researchcollaborationsurveys.org/ was used to measure the students' level of proficiency on self-regulation. Furthermore, the Students' Journal entries were used to collect the information and insights pertaining to the students' process of carrying out their assignments. Lastly, to support the data, a semistructured interview was employed. The researcher made some specific questions for the interview.

\section{Procedures}

The Self-Regulation Questionnaire (see Appendix) was used to measure the students' level of proficiency on self-regulation which includes five questions of planning, six questions of monitoring the plan, six questions of controlling and changing the plan, and five questions of reflecting on works. The Self-Regulation Questionnaires (SRQs) were given in Pre and Post Survey. Additionally, the surveys were taken by seventeen students. Meanwhile, every student was asked to write a journal at the end of research cycles 1 and 2. Overall, there were 34 journal entries. As it was stated before, the students' journals were used to collect the information and insights pertaining to the students' process of carrying out their assignments. Student journals have become part of students' work which can be one of the richest qualitative data sources (Pelton, 2010). Subsequently, to gain the data, the researcher classified the journals based on the definition of four essential components of self-regulation proposed by Noonan \& Erickson (2018):

Planning and articulating what they want to accomplish, monitoring progress and interference, taking control and making changes by implementing specific strategies when things are not going as planned, and reflecting on worked well and what they can do better next time. 
Lastly, the seventeen students were interviewed for 10 minutes each. The specific questions were made related to the students' ways of completing their assignments which include planning, monitoring, controlling, and reflecting, such as: Did you make any plan before doing your assignments? Why did you make a plan before doing your assignment? Did you monitor your plan? Why did you monitor your plan? Did you control and change your plan? Why did/ didn't you do that? How do you feel about the result of your work? Why did you do all those things? Like making a plan, monitoring the plan, controlling and changing the plan, and did a reflection. Do you think that YouTube (Vlogging) can motivate you to do your assignment better? Why? However, the flexibility of interview questions was still allowed depending on the response of the interviewees. Furthermore, the interview was conducted after the process of cycle 1 and 2 done. By doing this technique, the researcher could know the students' opinions and perceptions on the use of $2 \times 60$ minutes of structured assignment for promoting self-regulation using YouTube vlogging.

As the research employed a mixed-method approach, the data were first analyzed using a quantitative method. They were screened and analyzed using descriptive statistics and inferential statistics through Excel Microsoft Office. The raw data was keyed in through the system and descriptive statistics generated was used in order to analyze and interpret information. Thus, by using the Excel Microsoft Office system, descriptive statistics about all items can be analyzed more effectively and accurately. The information was analyzed and presented in the form of charts and tables. While the data gained from the interview were analyzed manually using the qualitative method.

Finally, to gain the trustworthiness the researcher used triangulation techniques. In this case, the researcher used two of the four triangulation techniques proposed by (Burns, 1999): Source triangulation in which the researcher used the interview of the participants to get the accuracy of data, and Theoretical triangulation that the researcher compared the data with relevant perspective theories.

\section{RESULTS}

The implementation of learning with the use of YouTube vlogging had been conducted using a Classroom Action Research which refers to the research proposed by Kemmis et al. (2014) includes planning, acting, observing, reflecting, replanning, new action, and observation, further reflecting. A two-cycle process of a CAR was applied in this research. To measure the students' improvement in their self-regulation, the researcher conducted Pre Survey and Post Survey, and students' journal entries.

The results of Pre-Survey showed that the average score was 70.4 which means that students needed to improve their self-regulation referring to the definition made by Noonan \& Erickson (2018), when the result of the scores gained from 22 questions on self-regulation formative questionnaires converted to a 100-point scale, the bottom quartile ranged from 20 to 72 and the top quartile ranged from 81 to 100 . In other word, it can be said that students were slightly under the average of the bottom quartile of the self-regulation range. In the PostSurvey, the results showed that the average score was 88 in. Thus, it can be said 
that students could reach the top quartile ranged of the scores. The result from the pre and post-survey can be seen in the following graph.

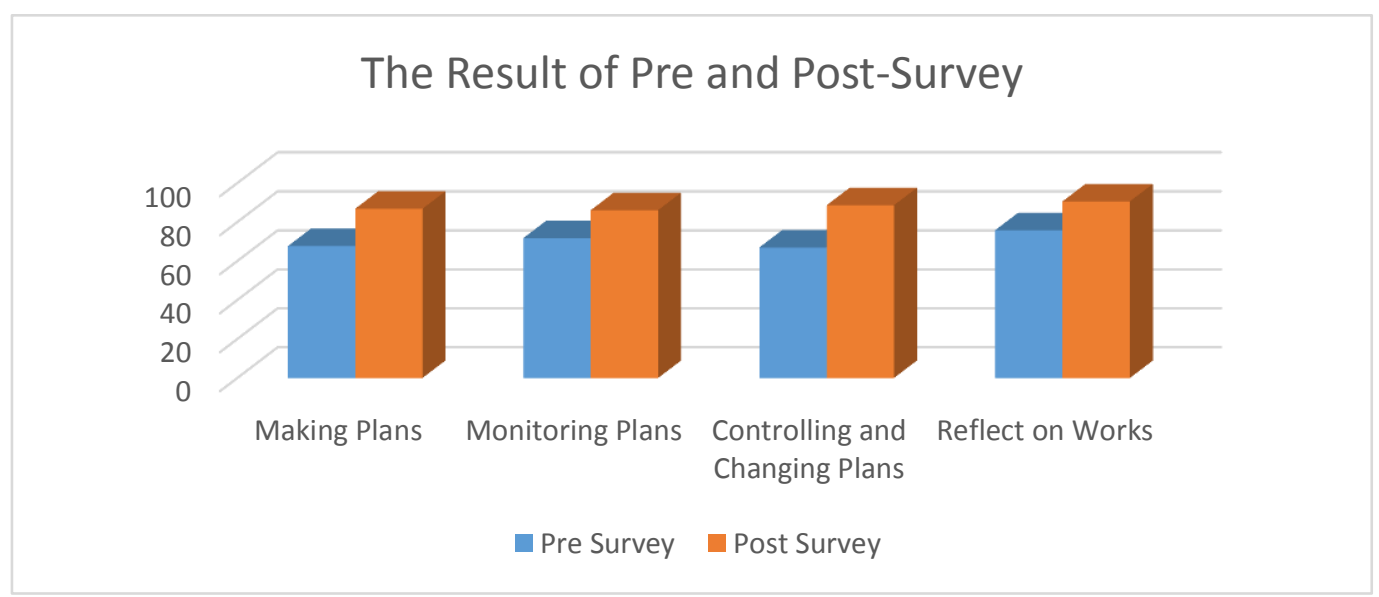

Fig 1: The results of Pre-Survey compared to Post-Survey

The other measurement used in this research was the students' journals. The journals were employed during Cycle 1 and Cycle 2 processes. The components used to measure students' self-regulation in the journals were just the same as the components used in the Pre Survey and Post Survey. They were planning, monitoring plans, controlling and changing plans, and reflecting on works. The final analysis of students' journals of Cycle 1 was that $58.8 \%$ of students had plans, $47 \%$ of students monitored the plans, $41.2 \%$ of students controlled and changed the plans, $17.6 \%$ of students reflected on their works. Furthermore, the problem found in Cycle 1 is similar to what Zimmerman wrote in his article. Students needed guidance to have appropriate plans before doing their assignments. Thus the researcher gave an intervention to students. It was by giving students Self-Regulation Worksheet and asking them to write the steps/ activities schedule in working or their assignment completed with the timeline of each activity before cycle 2 conducted. After having an analysis of students' journals in Cycle 2, it could be seen that the numbers of students were improving compared to Cycle 1. The following graph shows the students' journal entries of cycle 1 compared to cycle 2 :

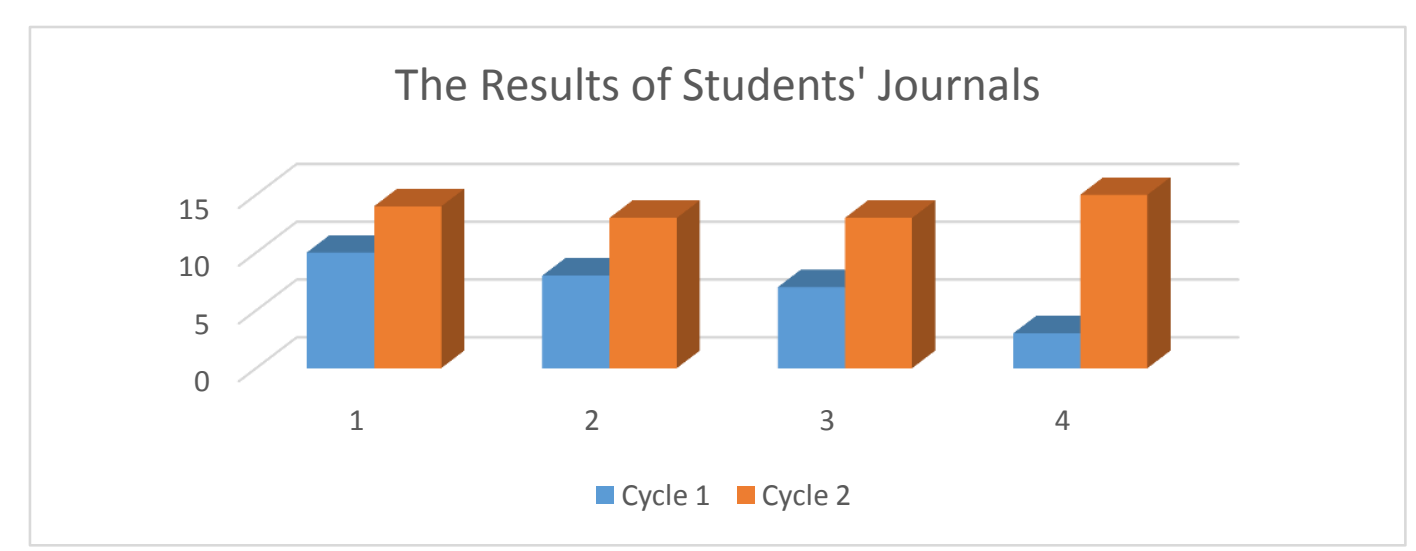

Fig 2: The results of students' journals in Cycle 1 and 2 
Based on the result of the analysis done, it can be considered that students could improve their self-regulation. However, it became important to find what could make students improve their self-regulation. First, both in Cycle 1 and Cycle 2, students were aware that their works were uploaded into the researcher's YouTube account. They knew that their work might be seen by many people. However, those components were not done appropriately in Cycle 1. The problem then was solved in Cycle 2 by teaching students to create better plans, monitoring, controlling and changing, and reflecting. Finally, it can be concluded that YouTube vlogging can improve students' self-regulation in English for Public Speaking class if students know the process of how to be self-regulated.

\section{CONCLUSION}

This classroom action research was conducted in two cycles. Based on the analysis which was done in the previous chapter about the use of YouTube vlogging to promote self-regulation in a public speaking class, the conclusion from this research are not statements such as, There is a significant improvement in the students' self-regulation made by YouTube vlogging in English for Public Speaking class. Instead, the evidence is presented which indicate that certain practices seem to enhance the students' learning process out of the classroom session.

The Quantitative data were taken from Self-regulation Questionnaire and two Students' Journal Entries. Based on the Post Survey, it was found that students improved their self-regulation by $15.4 \%$ comparing to the Pre Survey data analyses results. While the two Students' Journal Entries showed that the results of the second Students' Journal Entries indicated the students improved their self-regulation by $39.7 \%$ comparing to the first Students' Journal Entries. Furthermore, the results of Qualitative data analysis taken from the semi structured-interview also found that students were motivated and did the four components of self-regulation.

However, the researcher was curious and tried to have further analysis of whether the students' self-regulation improvement was caused by YouTube vlogging itself or helped by another party. After carrying out further analysis, the researcher concluded that the students' self-regulation improvement was not only caused by YouTube vlogging but also because of the students' understanding of how to plan well, then how to monitor the plans, control and change the plans if needed, and reflect on their works which was done by the researcher by giving an intervention at the beginning of Cycle 2 process.

Despite the limitations, there are valuable insights gained through this study so that the researcher wishes to give suggestions in this research. It is important for the students to know the components of self-regulation if they would like to be self-regulated persons. Based on the results found in this research, YouTube with its featured called video-blogging or vlogging can help a teacher/ lecturer to motivate students to do their assignment, especially in doing the 2 x 60 minutes of structured-assignment. Based on nature, YouTube is a media that provides vlogging menu where students' works can be posted and seen by others. Thus, this media can encourage students to do more seriously in their works. Furthermore, in educational utility, YouTube provides a lot of educational resources that can help the members of schools for the better process of education. 


\section{REFERENCES}

Alhamami, M. (2013). Observation on YouTube language learning videos (YouTube llvs). 13(3), 3-17.

Bandura, A. (1997). Self-efficacy: The exercise of control. New York: W.H. Freeman.

Beebe, S. A., \& Beebe, S. J. (2016). Public speaking handbook (Fifth Edition). Boston: Pearson.

Bell, L. M., \& Aldge, J. M. (2014). Student voice, teacher action research and classroom improvement. Retrieved from http://site.ebrary.com/id/10954917

Burns, A. (1999). Collaborative action research for English language teachers. Cambridge ; New York: Cambridge University Press.

DeWitt, D., Alias, N., Siraj, S., Yaakub, M. Y., Ayob, J., \& Ishak, R. (2013). The Potential of Youtube for Teaching and Learning in the Performing Arts. Procedia - Social and Behavioral Sciences, 103, 1118-1126. https://doi.org/10.1016/j.sbspro.2013.10.439

Dornyei, Z. (2005). The Psychology of the Language Learner. Retrieved from http://public.eblib.com/choice/publicfullrecord.aspx?p=5292890

Ekhlas, N. N., \& Shangarffam, N. (2013). The Relationship between Determinant Factors of Self-Regulation Strategies and Main Language Skills and Overall Proficiency. Procedia - Social and Behavioral Sciences, 70, 137-147. https://doi.org/10.1016/j.sbspro.2013.01.049

El-Sakka, S. M. F. (2016). Self-Regulated Strategy Instruction for Developing Speaking Proficiency and Reducing Speaking Anxiety of Egyptian University Students. English Language Teaching, 9(12), 22. https://doi.org/10.5539/elt.v9n12p22

Gilmer, P. J. (2010). Transforming University Biochemistry Teaching Using Collaborative Learning and Technology. https://doi.org/10.1007/978-14020-4981-1

Kemmis, S., McTaggart, R., \& Nixon, R. (2014). The action research planner: Doing critical participatory action research. Singapore Heidelberg New York Dordrecht London: Springer.

Lucas, S. (2009). The art of public speaking (10th ed). Boston: McGraw-Hill Higher Education.

Mahmoodi, M. H., Kalantari, B., \& Ghaslani, R. (2014). Self-Regulated Learning (SRL), Motivation and Language Achievement of Iranian EFL Learners. Procedia - Social and Behavioral Sciences, 98, 1062-1068. https://doi.org/10.1016/j.sbspro.2014.03.517

Ristekdikti. (2015, December 28). Peraturan Menteri Riset, Teknologi, dan Pendidikan Tinggi Republik Indonesia Nomor 44 Tahun 2015. Retrieved from https://jdih.ristekdikti.go.id/produk-hukum/?id=ea907f9b-1d77-491bbc2b-9f9c843be459

Santagata, R., \& Guarino, J. (2011). Using video to teach future teachers to learn from teaching. $Z D M, 43(1), 133-145$.

Turner, K. J., Osborn, R., Osborn, M., \& Osborn, S. (2018). Public speaking: Finding your voice (Eleventh edition). Hoboken, NJ: Pearson. 
Yot-Domínguez, C., \& Marcelo, C. (2017). University students' self-regulated learning using digital technologies. International Journal of Educational Technology in Higher Education, 14(1), 38. https://doi.org/10.1186/s41239017-0076-8

Zarei, A., \& Gilanian, M. (2015). Self-efficacy as a Function of Language Learning Strategy Use. British Journal of Education, Society \& Behavioural Science, 9(3), 223-235. https://doi.org/10.9734/BJESBS/2015/18735

Zimmerman, B. J. (2002). Becoming a Self-Regulated Learner: An Overview. Theory Into Practice, 41(2), 64-70. https://doi.org/10.1207/s15430421tip4102_2 


\section{Appendix}

\section{Questionnaire

\section{Self-Regulation Formative Questionnaire}

Please CHECK ONE response that best describes you. Be honest, since the information will be used to help you in school and also help you become more prepared for college and careers. There are no right or wrong answers!

Student ID

Date

\begin{tabular}{|c|c|c|c|c|c|}
\hline & \multicolumn{2}{|c|}{$\begin{array}{l}\text { Not very } \\
\text { like me }\end{array}$} & & & \multirow{2}{*}{$\begin{array}{c}\text { Very } \\
\text { like me } \\
5\end{array}$} \\
\hline & 1 & 2 & 3 & 4 & \\
\hline 1. I plan out projects that I want to complete. & $\square$ & $\square$ & $\square$ & $\square$ & $\square$ \\
\hline 2. If an important test is coming up, I create a study plan. & $\square$ & $\square$ & $\square$ & $\square$ & $\square$ \\
\hline 3. Before I do something fun, I consider all the things that I need to get done. & $\square$ & $\square$ & $\square$ & $\square$ & $\square$ \\
\hline 4. I can usually estimate how much time my homework will take to complete. & $\square$ & $\square$ & $\square$ & $\square$ & $\square$ \\
\hline 5. I have trouble making plans to help me reach my goals. & $\square$ & $\square$ & $\square$ & $\square$ & $\square$ \\
\hline 6. I keep track of how my projects are going. & $\square$ & $\square$ & $\square$ & $\square$ & $\square$ \\
\hline 7. I know when I'm behind on a project. & $\square$ & $\square$ & $\square$ & $\square$ & $\square$ \\
\hline 8. I track my progress for reaching my goal. & $\square$ & $\square$ & $\square$ & $\square$ & $\square$ \\
\hline 9. I know what my grades are at any given time. & $\square$ & $\square$ & $\square$ & $\square$ & $\square$ \\
\hline 10. Daily, I identify things I need to get done and track what gets done. & $\square$ & $\square$ & $\square$ & $\square$ & $\square$ \\
\hline 11. I have trouble remembering all the things I need to accomplish. & $\square$ & $\square$ & $\square$ & $\square$ & $\square$ \\
\hline 12. I do what it takes to get my homework done on time. & $\square$ & $\square$ & $\square$ & $\square$ & $\square$ \\
\hline $\begin{array}{l}\text { 13. I make choices to help me succeed, even when they aren't the most fun } \\
\text { right now. }\end{array}$ & $\square$ & $\square$ & $\square$ & $\square$ & $\square$ \\
\hline 14. As soon as I see things aren't going right, I want to do something about it. & $\square$ & $\square$ & $\square$ & $\square$ & $\square$ \\
\hline 15. I keep trying as many different possibilities as necessary to succeed. & $\square$ & $\square$ & $\square$ & $\square$ & $\square$ \\
\hline $\begin{array}{l}\text { 16. I have difficulty maintaining my focus on projects that take a long time to } \\
\text { complete. }\end{array}$ & $\square$ & $\square$ & $\square$ & $\square$ & $\square$ \\
\hline 17. When I get behind on my work, I often give up. & $\square$ & $\square$ & $\square$ & $\square$ & $\square$ \\
\hline 18. I think about how well I'm doing on my assignments. & $\square$ & $\square$ & $\square$ & $\square$ & $\square$ \\
\hline 19. I feel a sense of accomplishment when I get everything done on time. & $\square$ & $\square$ & $\square$ & $\square$ & $\square$ \\
\hline 20. I think about how well I've done in the past when I set new goals. & $\square$ & $\square$ & $\square$ & $\square$ & $\square$ \\
\hline 21. When I fail at something, I try to learn from my mistakes. & $\square$ & $\square$ & $\square$ & $\square$ & $\square$ \\
\hline 22. I keep making the same mistakes over and over again. & $\square$ & $\square$ & $\square$ & $\square$ & $\square$ \\
\hline
\end{tabular}

Gaumer Erickson, A.S. \& Noonan, P.M. (2018). Self-regulation formative questionnaire. In The skills that matter: Teaching interpersonal and intrapersonal competencies in any classroom (pp. 177-178). Thousand Oaks, CA: Corwin. 